\title{
Corrigendum: Dietary Fish, Fish Nutrients, and Immune Function: A Review
}

\section{OPEN ACCESS}

Edited and reviewed by: Philip Calder,

University of Southampton, United Kingdom

*Correspondence:

Carlos O. Mendivi

carlosolimpo@gmail.com;

cmendivi@uniandes.edu.co

Specialty section: This article was submitted to

Nutritional Immunology,

a section of the journal

Frontiers in Nutrition

Received: 12 April 2021 Accepted: 23 April 2021

Published: 19 May 2021

Citation:

Mendivil CO (2021) Corrigendum: Dietary Fish, Fish Nutrients, and Immune Function: A Review. Front. Nutr. 8:693773. doi: 10.3389/fnut.2021.693773

\section{Carlos O. Mendivil ${ }^{1,2 *}$ \\ ${ }^{1}$ School of Medicine, Universidad de los Andes, Bogotá, Colombia, ${ }^{2}$ Section of Endocrinology, Department of Internal Medicine, Fundación Santa Fe de Bogotá, Bogotá, Colombia}

Keywords: immunity, immune function, fish, omega-3, microbiota, seafood

\section{A Corrigendum on}

Dietary Fish, Fish Nutrients, and Immune Function: A Review

by Mendivil, C. O. (2021). Front. Nutr. 7:617652. doi: 10.3389/fnut.2020.617652

A correction has been made to Nutrients with immunomodulatory properties present in fish, Melatonin, third paragraph.

The sentence in mention has been changed from " $3.7 \mathrm{mg}$ per gram of raw food, or approximately $300-350 \mathrm{mg}$ ", to " $3.7 \mathrm{ng}$ per gram of raw food, or approximately $300-350 \mathrm{ng}$."

The author apologizes for this error and states that this does not change the scientific conclusions of the article in any way. The original article has been updated.

Copyright $\odot 2021$ Mendivil. This is an open-access article distributed under the terms of the Creative Commons Attribution License (CC BY). The use, distribution or reproduction in other forums is permitted, provided the original author(s) and the copyright owner(s) are credited and that the original publication in this journal is cited, in accordance with accepted academic practice. No use, distribution or reproduction is permitted which does not comply with these terms. 